\title{
Efficacy of Different Organic Manures and Inorganic Fertilizer on the Yield and Yield Attributes of Boro Rice
}

\author{
M. A. Hossaen ${ }^{1}$, A. T. M. Shamsuddoha ${ }^{1}$, A. K. Paul ${ }^{1}$, M. S. I. Bhuiyan ${ }^{1 *}$ and A. S. M. Zobaer ${ }^{2}$ \\ ${ }^{1}$ Department of Soil Science, ${ }^{2}$ Farm Division, Sher-e-Bangla Agricultural University, Dhaka1207, Bangladesh \\ *Corresponding author and Email: msibsau@gmail.com
}

Received: 21 July 2011

Accepted: 26 November 2011

\begin{abstract}
This study was conducted to evaluate the efficacy of different organic manure and inorganic fertilizer on the yield and yield attributes of Boro Rice (Oryza sativa L.). The experiment consisted of 8 treatments, $\mathrm{T}_{0}$ : Control, $\mathrm{T}_{1}: 100 \% \mathrm{~N}_{100} \mathrm{P}_{15} \mathrm{~K}_{45} \mathrm{~S}_{20}$ (Recommended dose), $\mathrm{T}_{2}: 50 \%$ NPKS +5 t cowdung $\mathrm{ha}^{-1}, \mathrm{~T}_{3}: 70 \% \mathrm{NPKS}+3 \mathrm{t}$ cowdung ha ${ }^{-1}, \mathrm{~T}_{4}: 50 \% \mathrm{NPKS}+4 \mathrm{t}$ poultry manure ha ${ }^{-1}, \mathrm{~T}_{5}: 70 \%$ NPKS + $2.4 \mathrm{t}$ poultry manure $\mathrm{ha}^{-1}, \mathrm{~T}_{6}: 50 \% \mathrm{NPKS}+5 \mathrm{t}$ vermicompost $\mathrm{ha}^{-1}$ and $\mathrm{T}_{7}: 70 \% \mathrm{NPKS}+3 \mathrm{t}$ vermicompost ha ${ }^{-1}$. At 30, 50, 70, 90 DAT and at harvest stage the tallest plant $(24.18,31.34,44.67$, 67.05 and $89.00 \mathrm{~cm}$ ) and the greatest number of total tiller per hill $(5.43,11.64,21.01$ and 17.90) at same DAT was recorded from $\mathrm{T}_{5}$ and the lowest was observed from $\mathrm{T}_{0}$ in every aspect. The maximum number of effective tillers per hill $(13.52)$, the longest panicle $(24.59 \mathrm{~cm})$, maximum number of total grain per plant (97.45), the highest weight of 1000 seeds $(21.80 \mathrm{~g})$, the maximum grain yield $(7.30 \mathrm{t}$ $\left.\mathrm{ha}^{-1}\right)$ and straw yield $\left(7.64 \mathrm{t} \mathrm{ha}^{-1}\right)$ was recorded from $\mathrm{T}_{5}$ treatment whereas the lowest number of effective tillers per hill $(6.07)$, the shortest panicle $(16.45 \mathrm{~cm})$, the minimum total grain per plant (69.13), the lowest weight of 1000 seeds $(16.73 \mathrm{~g})$, the lowest grain yield $\left(2.06 \mathrm{tha}^{-1}\right)$ and straw yield $\left(4.63 \mathrm{t} \mathrm{ha}^{-1}\right)$ was observed from $\mathrm{T}_{0}$ treatment. Although the highest biological yield was recorded from $\mathrm{T}_{5}$ treatment but statistically similar result were found from $\mathrm{T}_{3}, \mathrm{~T}_{4}$ and $\mathrm{T}_{7}$ treatments. The highest harvest index also recorded for $\mathrm{T}_{5}$ treatment. It was obvious that yield of rice can be increased substantially with the judicious application of organic manure with chemical fertilizer.
\end{abstract}

Keywords: Cowdung, poultry manure, vermicompost, NPKS, yield, yield contributing characters, boro rice

\section{Introduction}

Rice (Oryza sativa L.) is the staple food of Bangladesh. Among the three types of rice, boro rice covers about $56.66 \%$ of total rice area, which contributes $43.24 \%$ of the total rice production in the country (BBS, 2008). Rice is intensively cultivated in Bangladesh covering about $80 \%$ of arable land.

Unfortunately, the yield of rice is low considering the other rice growing countries like Japan and China where the average yield is 6.7 and $6.3 \mathrm{t}$ ha-1, respectively (FAO, 2004). A judicious combination of organic and inorganic sources of nutrients is necessary for sustainable agriculture that can ensure food production with high quality (Nambiar, 1991). Integrated use of organic manure and chemical fertilizers would be quite promising not only in providing greater stability in production, but also in maintaining better soil fertility. The long-term research at BARI revealed that the application of cowdung @ $5 \mathrm{t} \mathrm{ha}^{-1}$ year $^{-1}$ improved rice productivity as well as prevented the soil resources from degradation (Bhuiyan, 1994). Poultry manure is another good source of nutrients in soil. Meelu and Singh (1991) showed that $4 \mathrm{t} \mathrm{ha}^{-1}$ poultry 
manure along with $60 \mathrm{~kg} \mathrm{~N} \mathrm{ha}^{-1}$ as urea produce grain yield of crop similar to that with $120 \mathrm{~kg}$ $\mathrm{Nha}^{-1}$ as urea alone. Organic manure can supply a good amount of plant nutrients and therefore can contribute to crop yields. Therefore, it is necessary to use fertilizer and manure in an integrated way in order to obtain sustainable crop yield without declining soil fertility. The increasing land use intensity has resulted in a great exhaustion of nutrient in soils. In Bangladesh, most of the cultivated soils have less than $1.5 \%$ organic matter while a good agricultural soil should contain at least $2 \%$ organic matter. Moreover, this important component of soil is declining with time due to intensive cropping and use of higher dose of chemical fertilizers with little or no addition of organic manure in the farmer's field. Soil organic matter improves the physicochemical properties of the soil and ultimately promotes crop production. Evidences from different AEZ of the country have shown a decrease in the content of organic matter by the range of 15 to $30 \%$ over the last 20 years (Miah, 1994). Therefore, it would not be wise to depend only on inherent potentials of soils for higher crop production. More recently, attention is given on the utilization of organic wastes, farm yard manure (FYM), compost, vermicompost and poultry manures as the most effective measure for the improving soil fertility and thereby crop productivity. The application of different fertilizers and manures influences the physical and chemical properties of soil and enhances the biological activities. It is also positively correlated with soil porosity and enzymatic activity. Applications of both chemical and organic fertilizers need to be applied for the improvement of soil physical properties and supply of essential plant nutrients for higher yield. The present investigation was, therefore, undertaken to develop a suitable integrated dose of inorganic fertilizers and organic manures for Boro rice and to observe the effects of different levels of inorganic fertilizers and organic manures on the yield as well as yield components of Boro rice.

\section{Materials and Methods}

The experiment was conducted in the Farm $\left(23^{\circ} 46^{\prime} 16.18 " \mathrm{~N}\right.$ latitude and $90^{\circ} 222^{\prime} 36.54^{\prime \prime} \mathrm{E}$ longitude) of Sher-e-Bangla Agricultural University, Dhaka, Bangladesh during December 2007 to April 2008 to study the efficacy of various organic manure and inorganic fertilizers on the yield and yield attributes of boro rice ( BRRI dhan 29). The climate of the experimental area is characterized by high temperature, high humidity and medium rainfall during the kharif season (March-September) and a scanty rainfall associated with moderately low temperature in the rabi season (October-February). The land was first opened on 24 October, 2007 by a tractor and prepared thoroughly by ploughing and cross ploughing with a power tiller and country plough. Finally each plot was prepared by puddling. The experiment was laid out in a randomized complete block design (RCBD), with four blocks. Each block was divided into eight unit plots as treatments with raised bunds around. The unit plot size was $2 \mathrm{~m} \times 2 \mathrm{~m}\left(4 \mathrm{~m}^{2}\right)$. The distance maintained between two blocks and two plots were $1.0 \mathrm{~m}$ and $0.5 \mathrm{~m}$, respectively. Before land preparation, initial composite soil sample were collected at $0-15 \mathrm{~cm}$ depth from different spots and prepared for physical and chemical analysis. The experimental site is fairly level, well drained and belongs to Deep Red Brown Terrace Soil under Madhupur Tract (AEZ- 28). The physical and chemical characteristics of initial soils are given in the Table 1. 
Table 1. Some physical and chemical properties of the initial soil

\begin{tabular}{lc}
\multicolumn{1}{c}{ Characteristics } & Value \\
\hline Mechanical fractions: \% Sand $(2.0-0.02 \mathrm{~mm}), \%$ Silt & $22.26,56.72,20.75$ \\
$(0.02-0.002 \mathrm{~mm}), \%$ Clay $(<0.002 \mathrm{~mm})$ & Silt Loam \\
Textural class & Granular and friable when dry. \\
Consistency & 5.8 \\
pH $\left(1: 2.5 \mathrm{soil}^{-}\right.$water $)$ & 17.9 \\
CEC $\left(\mathrm{cmolkg}^{-1}\right)$ & 0.686 \\
Organic C $(\%)$ & 1.187 \\
Organic Matter $(\%)$ & 0.08 \\
Total N $(\%)$ & 0.12 \\
Exchangeable K $\left(\mathrm{cmolkg}^{-1}\right)$ & 19.85 \\
Available P $\left(\mathrm{mgkg}^{-1}\right)$ & 14.40 \\
Available S $\left(\mathrm{mgkg}^{-1}\right)$ & \\
\hline
\end{tabular}

Table 2. Chemical compositions of the cowdung, poultry manure and vermicompost (oven dry basis)

\begin{tabular}{ccccccc}
\hline \multirow{2}{*}{$\begin{array}{c}\text { Name of organic } \\
\text { manure }\end{array}$} & $\mathrm{C}$ & $\mathrm{N}$ & $\mathrm{P}$ & $\mathrm{K}$ & $\mathrm{S}$ & \multirow{2}{*}{ C:N ratio } \\
\cline { 2 - 5 } & 36 & 1.48 & 0.29 & 0.75 & 0.21 & 24 \\
Cowdung & 29 & 2.19 & 1.98 & 0.81 & 0.34 & 8 \\
Poultry manure & 48 & 2.99 & 0.28 & 1.65 & 0.32 & 15 \\
Vermicompost & & & & & &
\end{tabular}

The experiment consisted of 8 treatments. The treatments were as follows $\mathrm{T}_{0}$ : Control, $\mathrm{T}_{1}: 100 \%$ $\mathrm{N}_{100} \mathrm{P}_{15} \mathrm{~K}_{45} \mathrm{~S}_{20}$ (Recommended dose) (Fertilizer Recommendation Guide, 2005), $\mathrm{T}_{2}: 50 \%$ NPKS $+5 \mathrm{t}$ cowdung $\mathrm{ha}^{-1}, \mathrm{~T}_{3}: 70 \% \mathrm{NPKS}+3 \mathrm{t}$ cowdung ha ${ }^{-1}, \mathrm{~T}_{4}: 50 \% \mathrm{NPKS}+4 \mathrm{t}$ poultry manure $\mathrm{ha}^{-1}, \mathrm{~T}_{5}: 70 \% \mathrm{NPKS}+2.4 \mathrm{t}$ poultry manure $\mathrm{ha}^{-1}, \mathrm{~T}_{6}: 50 \%$ NPKS $+5 \mathrm{t}$ vermicompost ha $^{-1}$ and $\mathrm{T}_{7}: 70 \%$ NPKS $+3 \mathrm{t}$ vermicompost $\mathrm{ha}^{-1}$. Full amounts of TSP, MP and gypsum were applied as basal dose. Urea were applied in 3 equal splits: one third was applied at basal before transplanting, one third at active tillering stage (30 DAT) and the remaining one third was applied before panicle initiation stage (55 DAT). The rates of manure were $3 \& 5,2.4 \& 4$ and $3 \&$ $5 \mathrm{t} \mathrm{ha}^{-1}$ for cow dung, poultry manure and vermicompost per plot were calculated as per the treatments, respectively. As organic manure cowdung, poultry manures and vermicompost were applied before four days of final land preparation. Chemical compositions of the manures have been presented in Table 2.

Seeds (95\% germination) @ $5 \mathrm{~kg} \mathrm{ha}^{-1}$ were soaked and incubated for 48 hour and sown on a well-prepared seed bed. Forty days old seedlings of BRRI dhan 29 were carefully uprooted from the seed bed and transplanted on 12 January, 2008 in the field. Two seedlings per hill were used following a spacing of $20 \mathrm{~cm} \mathrm{x} 20 \mathrm{~cm}$. Intercultural operations were done when necessary. Leaf roller (Chaphalocrosis medinalis, Pyralidae, Lepidoptera) was observed and used Malathion@1.12 $\mathrm{L} \mathrm{ha}^{-1}$ to control. The crop was harvested at full maturity on 24 April, 2008. The height of plant was recorded from the ground level to the tip of the panicle in centimeter $(\mathrm{cm})$ at the time of 30, 50, 70, 90 days 
and at harvesting stage. The number of tiller hill ${ }^{-}$

${ }^{1}$ was recorded at the time of $30,50,70$ and 90 days by counting total tillers. Data were recorded as the average of 10 plants selected at random from the inner $1 \mathrm{~m}^{2}$ area of each plot and average was recorded. The total number of effective tiller hill $^{-1}$ was counted as the number of panicle bearing plant hill $^{-1}$ and total number of noneffective tillers hill $^{-1}$ was counted as the number of non-panicle bearing plant hill ${ }^{-1}$. The total number of tillers hill ${ }^{-1}$ was counted as the number of effective tillers hill $^{-1}$ and noneffective tillers hill ${ }^{-1}$. The length of panicle was measured with a meter scale. The total numbers of filled grain and unfilled grain were counted based on nature of grains present in panicle. The total numbers of grain was counted by adding number of filled and unfilled grain. One thousand seeds were counted randomly from the total cleaned harvested seeds and then weighted in grams and recorded. The dry weight of grains of central $1 \mathrm{~m}^{2}$ area per unit plot were recorded and finally converted to $\mathrm{tha}^{-1}$. The dry weight of straw of central $1 \mathrm{~m}^{2}$ area per unit plot were recorded and finally converted to $\mathrm{tha}^{-1}$. The harvest index and biological yield were calculated with the following formula:

Harvest index $(\mathrm{HI})=\frac{\text { Economic yield }(\text { grain wei ght })}{\text { Biological yield }(\text { Total dry weight })} x 100$

Where, Biological yield $=$ grain yield + straw yield. The data obtained for different parameters were statistically analyzed to find out the significant difference of different treatments on yield and yield contributing characters of BRRI dhan 29. The mean values of all the characters were calculated and analysis of variance was performed by the ' $\mathrm{F}$ ' (variance ratio) test. The significance of the difference among the treatment means was estimated by the Duncan's Multiple Range Test (DMRT) at 5\% level of probability (Gomez and Gomez, 1984).

\section{Results and Discussion}

Statistically significant variation was recorded for plant height of BRRI dhan 29 due to the application of various organic manure and inorganic fertilizers at 30, 50, 70, 90 DAT and at harvest. At the different days after transplanting (DAT) the highest plant height $(24.18 \mathrm{~cm}, 31.34$ $\mathrm{cm}, 44.67 \mathrm{~cm}, 67.05 \mathrm{~cm}$ and $89.00 \mathrm{~cm}$ ) was recorded in $\mathrm{T}_{5}(70 \% \mathrm{NPKS}+2.4 \mathrm{t}$ poultry manure $\mathrm{ha}^{-1}$ ) treatment which was statistically similar $(23.95 \mathrm{~cm}, 30.80 \mathrm{~cm}, 44.25 \mathrm{~cm}, 65.70 \mathrm{~cm}$ and $86.54 \mathrm{~cm})$ to $\mathrm{T}_{3}(70 \% \mathrm{NPKS}+3 \mathrm{t}$ cowdung $\mathrm{ha}^{-1}$ ) treatment at $30,50,70,90 \mathrm{DAT}$ and at harvest, respectively. Whereas, at the same DAT the lowest plant height $(16.20 \mathrm{~cm}, 20.65 \mathrm{~cm}$, $32.58 \mathrm{~cm}, 49.10 \mathrm{~cm}$ and $64.59 \mathrm{~cm}$ ) was observed from $\mathrm{T}_{0}$ treatment, which was closely followed $(19.70 \mathrm{~cm}, 24.88 \mathrm{~cm}, 39.85 \mathrm{~cm}, 58.20 \mathrm{~cm}$ and $76.23 \mathrm{~cm})$ by $\mathrm{T}_{6}(50 \%$ NPKS $+5 \mathrm{t}$ vermicompost $\mathrm{ha}^{-1}$ ) treatment (Table 3). From the data it revealed that all the treatments produced significantly taller plants compared to the control treatment. The combined application of fertilizers and manures influence on plant height compared to single application of any one. Plant height was significantly influenced by the application of organic manure and chemical fertilizers reported by Babu et al. (2001). Similar results also reported by Rajani Rani et al. (2001), Singh et al. (1999), Hossain et al. (1997) and Sharma and Mitra (1991) also observed similar results.

Number of tillers per hill showed statistically significant variation due to the application of various organic manure and inorganic fertilizer at 30, 50, 70 and 90 DAT. At the mentioned days after transplanting (DAT) the maximum number of total tillers per hill $(5.43,11.64,21.01$ and 17.90) was observed from $\mathrm{T}_{5}(70 \%$ NPKS $+2.4 \mathrm{t}$ poultry manure $\mathrm{ha}^{-1}$ ) treatment which was statistically identical $(5.01,11.09,20.54$ and $16.78)$ with $T_{3}\left(70 \%\right.$ NPKS +3 t cowdung ha $\left.{ }^{-1}\right)$ gat the same DAT, respectively (Table 3 ). Again at the same DAT the minimum number of total tillers per hill $(2.51,4.60,10.29$ and 7.26) was observed from $\mathrm{T}_{0}$ treatment which was closely followed $\left(3.39,7.30,15.40\right.$ and 11.47) by $\mathrm{T}_{6}$ $\left(50 \%\right.$ NPKS +5 t vermicompost ha $\left.{ }^{-1}\right)$ tratment (Table 3). 
Table 3. Effect of various organic manure and inorganic fertilizer on plant height and number of total tiller per hill of boro rice BRRI dhan 29

\begin{tabular}{|c|c|c|c|c|c|c|c|c|c|}
\hline \multirow{2}{*}{ Treatment } & \multicolumn{5}{|c|}{ Plant height $(\mathrm{cm})$} & \multicolumn{4}{|c|}{ Number of total tiller per hill } \\
\hline & 30 DAT & $50 \mathrm{DAT}$ & 70 DAT & 90 DAT & at harvest & $30 \mathrm{DAT}$ & $50 \mathrm{DAT}$ & 70 DAT & 90 DAT \\
\hline Control & $16.20 \mathrm{c}$ & $20.65 \mathrm{~d}$ & $32.58 \mathrm{c}$ & $49.10 \mathrm{e}$ & $64.59 \mathrm{e}$ & $2.51 \mathrm{e}$ & $4.60 \mathrm{e}$ & $10.29 \mathrm{f}$ & $7.26 \mathrm{f}$ \\
\hline $\begin{array}{l}\text { 100\% N100 P15K } 45 \mathrm{~S}_{20} \\
\text { (Recommended dose) }\end{array}$ & $21.90 \mathrm{ab}$ & $29.17 \mathrm{ab}$ & $42.41 \mathrm{ab}$ & 62.42 be & 83.60 be & $4.13 \mathrm{c}$ & 9.59 be & $16.92 \mathrm{de}$ & $13.79 \mathrm{~cd}$ \\
\hline $50 \%$ NPKS $+5 t_{\text {cowdungha }}{ }^{-1}$ & $21.20 \mathrm{ab}$ & 27.65 be & $42.00 \mathrm{ab}$ & $60.81 \mathrm{~cd}$ & $80.90 \mathrm{c}$ & $3.95 \mathrm{c}$ & $8.81 \mathrm{~cd}$ & $17.40 \mathrm{~cd}$ & $13.09 \mathrm{de}$ \\
\hline $70 \%$ NPKS $+3 \mathrm{t}$ cowdungha ${ }^{-1}$ & $23.95 \mathrm{a}$ & $30.80 \mathrm{ab}$ & $44.25 \mathrm{a}$ & $65.70 \mathrm{ab}$ & $86.54 \mathrm{ab}$ & $5.01 \mathrm{ab}$ & $11.09 \mathrm{ab}$ & $20.54 \mathrm{ab}$ & $16.78 \mathrm{ab}$ \\
\hline $50 \% \mathrm{NPKS}+4 \mathrm{t}$ poultry manure $\mathrm{ha}^{-1}$ & $21.65 \mathrm{ab}$ & $29.58 \mathrm{ab}$ & $42.53 \mathrm{ab}$ & $64.58 \mathrm{abc}$ & $86.09 \mathrm{ab}$ & $4.66 \mathrm{~b}$ & 9.69 be & $18.49 \mathrm{~cd}$ & 15.12 be \\
\hline $\begin{array}{l}70 \% \text { NPKS }+2.4 \text { t poultry manure } \\
\text { ha }^{-1}\end{array}$ & $24.18 \mathrm{a}$ & $31.34 \mathrm{a}$ & $44.67 \mathrm{a}$ & $67.05 \mathrm{a}$ & $89.00 \mathrm{a}$ & $5.43 \mathrm{a}$ & $11.64 \mathrm{a}$ & $21.01 \mathrm{a}$ & $17.90 \mathrm{a}$ \\
\hline $50 \%$ NPKS $+5 \mathrm{t}$ vermicompost $\mathrm{ha}^{-1}$ & $19.70 \mathrm{~b}$ & $24.88 \mathrm{c}$ & $39.85 \mathrm{~b}$ & $58.20 \mathrm{~d}$ & $76.23 \mathrm{~d}$ & $3.39 \mathrm{~d}$ & $7.30 \mathrm{~d}$ & $15.40 \mathrm{e}$ & $11.47 \mathrm{e}$ \\
\hline $70 \%$ NPKS +3 t vermicompost ha $^{-1}$ & $22.20 \mathrm{ab}$ & $29.17 \mathrm{ab}$ & 43.10ab & $65.00 \mathrm{ab}$ & $86.43 \mathrm{ab}$ & $4.64 \mathrm{~b}$ & 9.65 be & 19.01 be & $14.96 \mathrm{bed}$ \\
\hline $\operatorname{LSD}(0.05)$ & 2.723 & 3.037 & 3.097 & 3.773 & 3.580 & 0.458 & 1.565 & 1.695 & 1.834 \\
\hline
\end{tabular}

In a column means having similar letter(s) are statistically identical and those having dissimilar letter(s) differ significantly as per 0.01 level of probability 
Table 4. Effect of various organic manure and inorganic fertilizer on yield contributing character and yield of boro rice BRRI dhan 29

\begin{tabular}{|c|c|c|c|c|c|c|c|c|c|c|c|c|}
\hline Treatment & $\begin{array}{l}\text { Number } \\
\text { of } \\
\text { effective } \\
\text { tiller /hill }\end{array}$ & $\begin{array}{c}\text { Number } \\
\text { of non- } \\
\text { effectiv } \\
e \\
\text { tiller/hil }\end{array}$ & $\begin{array}{l}\text { Total } \\
\text { tiller/ } \\
\text { hillll }\end{array}$ & $\begin{array}{l}\text { Length } \\
\text { of } \\
\text { Panicle } \\
(\mathrm{cm})\end{array}$ & $\begin{array}{c}\text { Number } \\
\text { of filled } \\
\text { grain/pl } \\
\text { ant }\end{array}$ & $\begin{array}{c}\text { Number } \\
\text { of } \\
\text { unfilled } \\
\text { grain/ } \\
\text { plant }\end{array}$ & $\begin{array}{c}\text { Number } \\
\text { of total } \\
\text { grain/ } \\
\text { plant }\end{array}$ & $\begin{array}{l}\text { Weight } \\
\text { of } 1000 \\
\text { Seed }(g)\end{array}$ & $\begin{array}{l}\text { Grain } \\
\text { yield } \\
\text { (t ha-1) }\end{array}$ & $\begin{array}{l}\text { Straw } \\
\text { Yield } \\
\text { (t ha- } \\
1 \text { ) }\end{array}$ & $\begin{array}{l}\text { Biolo } \\
\text { gical } \\
\text { yield } \\
\text { (t ha- } \\
1)\end{array}$ & $\begin{array}{c}\text { Harvest } \\
\text { index (\%) }\end{array}$ \\
\hline Control & $6.07 \mathrm{~d}$ & $4.32 \mathrm{a}$ & $10.40 \mathrm{~d}$ & $16.45 \mathrm{~d}$ & $55.72 \mathrm{e}$ & $13.40 \mathrm{a}$ & $69.13 \mathrm{~d}$ & $16.73 \mathrm{c}$ & $2.06 \mathrm{f}$ & $4.63 \mathrm{e}$ & $6.69 \mathrm{~d}$ & $30.81 \mathrm{e}$ \\
\hline $\begin{array}{l}100 \% \text { N100 P15K } 45 \mathrm{~S}_{20} \\
\text { (Recommended dose) }\end{array}$ & $11.32 \mathrm{~b}$ & $2.93 \mathrm{~cd}$ & $14.26 \mathrm{~b}$ & $22.91 \mathrm{abc}$ & 84.13 be & $8.17 \mathrm{c}$ & $92.29 \mathrm{ab}$ & $20.60 \mathrm{ab}$ & $5.53 \mathrm{~d}$ & 6.52 be & $12.05 \mathrm{~b}$ & 45.89 bed \\
\hline $50 \%$ NPKS $+5 t_{\text {cowdungha }}{ }^{-1}$ & $9.77 \mathrm{c}$ & $2.88 \mathrm{~cd}$ & $12.66 \mathrm{c}$ & $21.97 \mathrm{be}$ & $80.28 \mathrm{c}$ & 8.77 be & 89.05 be & $20.33 \mathrm{ab}$ & $4.80 \mathrm{e}$ & $5.86 \mathrm{~cd}$ & $10.66 \mathrm{c}$ & $44.92 \mathrm{~cd}$ \\
\hline $70 \%$ NPKS $+3 t$ cowdungha ${ }^{-1}$ & 13.23 a & $3.82 \mathrm{ab}$ & $17.04 \mathrm{a}$ & $23.37 \mathrm{ab}$ & 89.85 a & $7.12 \mathrm{~d}$ & 96.97 a & $21.50 \mathrm{ab}$ & $6.99 \mathrm{ab}$ & $7.50 \mathrm{a}$ & $14.49 \mathrm{a}$ & $48.22 \mathrm{ab}$ \\
\hline $50 \%$ NPKS $+4 \mathrm{t}$ poultry manure $\mathrm{ha}^{-1}$ & $11.60 \mathrm{~b}$ & $3.14 \mathrm{c}$ & $14.74 \mathrm{~b}$ & $22.88 \mathrm{abc}$ & $88.22 \mathrm{ab}$ & $8.12 \mathrm{c}$ & $96.35 \mathrm{a}$ & 21.10ab & $6.32 \mathrm{c}$ & $7.38 \mathrm{a}$ & $13.70 \mathrm{a}$ & 46.26 cbe \\
\hline $70 \% \mathrm{NPKS}+2.4 \mathrm{t}$ poultry manure ha- 1 & $13.52 \mathrm{a}$ & $2.27 \mathrm{~d}$ & $17.65 \mathrm{a}$ & $24.59 \mathrm{a}$ & $91.63 \mathrm{a}$ & $5.83 \mathrm{e}$ & $97.45 \mathrm{a}$ & $21.80 \mathrm{a}$ & $7.30 \mathrm{a}$ & $7.64 \mathrm{a}$ & $14.94 \mathrm{a}$ & $48.84 \mathrm{a}$ \\
\hline $50 \%$ NPKS $+5 t$ vermicompost ha ${ }^{-1}$ & $9.20 \mathrm{c}$ & $4.12 \mathrm{a}$ & $11.47 \mathrm{~cd}$ & $20.93 c$ & $74.70 \mathrm{~d}$ & $9.57 \mathrm{~b}$ & $84.27 \mathrm{c}$ & $19.88 \mathrm{~b}$ & $4.55 \mathrm{e}$ & $5.67 \mathrm{~d}$ & $10.22 \mathrm{c}$ & $44.53 \mathrm{~d}$ \\
\hline $70 \%$ NPKS $+3 \mathrm{t}$ vermicompost ha ${ }^{-1}$ & $12.23 \mathrm{~b}$ & 3.18 be & $15.41 \mathrm{~b}$ & $22.83 \mathrm{abc}$ & $88.15 \mathrm{ab}$ & $6.66 \mathrm{de}$ & $94.81 \mathrm{a}$ & $21.42 \mathrm{ab}$ & 6.44 be & $7.21 \mathrm{ab}$ & $13.65 \mathrm{a}$ & 47. $17 \mathrm{abc}$ \\
\hline $\operatorname{LSD}(0.05)$ & 0.974 & 0.643 & 1.290 & 1.927 & 5.151 & 0.963 & 5.081 & 1.518 & 0.608 & 0.751 & 1.243 & 2.295 \\
\hline
\end{tabular}

In a column means having similar letter(s) are statistically identical and those having dissimilar letter(s) differ significantly as per 0.01 level of probability 
It revealed that all the treatments influenced significantly maximum number of tiller compared to the control treatment. The maximum number of effective tillers per hill (13.52) was found from $\mathrm{T}_{5} \quad 70 \% \mathrm{NPKS}+2.4 \mathrm{t}$ poultry manure $\mathrm{ha}^{-1}$ ) treatment which was statistically identical (13.23) with $\mathrm{T}_{3}$ ( $70 \%$ NPKS +3 t cowdungha $^{-1}$ ). On the other hand, the minimum number of effective tillers per hill (6.07) was recorded from control treatment which was closely followed $(9.20)$ by $\mathrm{T}_{6}(50 \%$ NPKS + 5 t vermicompost ha ${ }^{-1}$ ) (Table 4). BRRI dhan 29 responded significantly better to chemical fertilizers when applied at the recommended doses than the manure when applied singly or combined application of $70 \%$ of manure and chemical fertilizers. Chander and Pandey (1996) reported a significant increase in effective tillers hill ${ }^{-1}$ due to application of higher doses of nitrogen. Number of in-effective tillers per hill of BRRI dhan 29 varied significantly due to the application of various organic manure and inorganic fertilizers. The maximum number of in-effective tillers per hill (4.32) was obtained from $\mathrm{T}_{0}$ as control condition which was statistically similar (4.32) by $\mathrm{T}_{6}(50 \% \mathrm{NPKS}+5$ $\mathrm{t}$ vermicompost $\mathrm{ha}^{-1}$ ) treatment. Whereas, the minimum number of in-effective tillers per hill (2.27) was found from $\mathrm{T}_{5}(70 \%$ NPKS $+2.4 \mathrm{t}$ poultry manure $\mathrm{ha}^{-1}$ ) treatment (Table 4$)$.

In case of total tillers per hill, $\mathrm{T}_{5}(70 \% \mathrm{NPKS}+$ $2.4 \mathrm{t}$ poultry manure $\mathrm{ha}^{-1}$ ) treatment showed the highest performance (17.65) which was statistically similar (17.04) to $\mathrm{T}_{3}(70 \% \mathrm{NPKS}+3$ $\mathrm{t}$ cowdung $\mathrm{ha}^{-1}$ ) treatment. On the other hand, the minimum (10.40) was obtained from $T_{0}$ treatment which was closely followed (11.47) by $\mathrm{T}_{6}\left(50 \% \mathrm{NPKS}+5 \mathrm{t}\right.$ vermicompost $\left.\mathrm{ha}^{-1}\right)$ treatment. The longest panicle $(24.59 \mathrm{~cm})$ was found from $\mathrm{T}_{5}(70 \%$ NPKS $+2.4 \mathrm{t}$ poultry manure $\left.\mathrm{ha}^{-1}\right)$ treatment which was statistically similar $(23.37 \mathrm{~cm})$ to $\mathrm{T}_{3}(70 \% \mathrm{NPKS}+3 \mathrm{t}$ cowdung ha ${ }^{-1}$ ) treatment. On the other hand, the shortest panicle $(16.45 \mathrm{~cm})$ was observed from control condition which was closely followed $(20.93 \mathrm{~cm})$ by $\mathrm{T}_{6} \quad(50 \% \mathrm{NPKS}+5 \mathrm{t}$ vermicompost $\mathrm{ha}^{-1}$ ) treatment (Table 4). BRRI dhan 29 responded significantly better-combined application of $70 \%$ chemical fertilizers with organic manure. Haque (1999) noted a significant increase in panicle length due to the application of organic manure and chemical fertilizers. Babu et al. (2001), Ahmed and Rahman (1991) and Apostol (1989) also reported similar results.

Similarly, $\mathrm{T}_{5}(70 \%$ NPKS $+2.4 \mathrm{t}$ poultry manure $\mathrm{ha}^{-1}$ ) treatment produced the greatest number of filled grain per plant (91.63) which was statistically identical (89.85) with $\mathrm{T}_{3} \quad(70 \%$ NPKS $+3 \mathrm{t}$ cowdung $\left.\mathrm{ha}^{-1}\right)$ treatment. Whereas, control showed the minimum (55.72) performed which was closely followed (74.70) by $\mathrm{T}_{6}(50 \%$ NPKS $+5 \mathrm{t}$ vermicompost $\left.\mathrm{ha}^{-1}\right)$ treatment. The minimum number of unfilled grain per plant (5.83) was recorded from $\mathrm{T}_{5}$. On the other hand, the maximum number of unfilled grain per plant (13.40) was recorded from control condition (Table 4).

$\mathrm{T}_{3}\left(70 \%\right.$ NPKS $+3 \mathrm{t}$ cowdung $\left.\mathrm{ha}^{-1}\right)$ treatment showed the highest number of total grain per plant (96.97) which was statistically identical with $\mathrm{T}_{4}, \mathrm{~T}_{5}, \mathrm{~T}_{7}$ treatment. On the other hand, the minimum number of total gram per plant (69.13) was recorded from $T_{0}$ treatment (Table 4 ). The effect of manure on increasing the number of grains panicle ${ }^{-1}$ was more pronounced as compared to fertilizers. This might be due to more availability of nutrient from the manure. Grains/panicle significantly increased due to the application of organic manures and chemical fertilizers (Razzaque, 1996). These results are also in agreement with Hoque (1999).

Weight of 1000 seeds of BRRI dhan 29 showed statistically significant variation due to the application of various organic manure and inorganic fertilizer. The greatest weight of 1000 seeds $(21.80 \mathrm{~g})$ was found from $\mathrm{T}_{5}(70 \% \mathrm{NPKS}+$ 2.4 t poultry manure $\mathrm{ha}^{-1}$ ) treatment whereas, the minimum weight of 1000 seeds $(16.73 \mathrm{~g})$ was observed from control treatment (Table 4). Abedin et al. (1999) reported that the combined application of organic manure and chemical 
fertilizers increased the 1000-grain weight of rice. Apostol (1989) observed that application of organic manure and chemical fertilizer increased 1000-grain weight of rice. Hoque (1999) also recorded that 1000 -grain weight were increased by the application of organic manure. Statistically similar thousand-grain weight was observed in maximum treatments.

In case of grain yield, $\mathrm{T}_{5}(70 \% \mathrm{NPKS}+2.4 \mathrm{t}$ poultry manure ha- $^{1}$ ) performed the highest result $\left(7.30 \mathrm{t} \mathrm{ha}^{-1}\right)$. On the other hand, the lowest grain yield $\left(2.06 \mathrm{t} \mathrm{ha}^{-1}\right)$ was found from control condition (Table 4). Application of NPKS increasing the grain yield of BRRI dhan 29 as compared to poultry manure and cowdung. $\mathrm{T}_{3}$ (70\% NPKS $+3 \mathrm{t} \mathrm{ha}^{-1}$ cowdung) treatment failed to produce the highest grain yield may be for lodging. Devivedi and Thakur (2000) reported the grain yield was significantly increased due to application of organic manure and chemical fertilizers. This is also in agreement with the findings of Rajni Rani et al. (2001), Haque et al. (2001) and Ahmed and Rhaman (1991). Statistically identical straw yield was obtained from $\mathrm{T}_{5}, \mathrm{~T}_{4}$, and $\mathrm{T}_{3}$ treatment which were higher record. On the other hand, the lowest straw yield $\left(4.63 \mathrm{t} \mathrm{ha}^{-1}\right)$ was found from $\mathrm{T}_{0}$ treatment (Table 3). Ahmed and Rahman (1991) reported that the application of organic manure and chemical fertilizers increased the straw yields of rice. These findings are well corroborated with the work of Islam (1997) and Khan (1998). It is clear that combination of organic manures and inorganic fertilizers encouraged vegetative growth of plants and thereby increasing straw yield. The highest biological yield (14.94 t ha-1) was recorded from $T_{5}$ which was statistically identical (14.49 $\mathrm{t} \mathrm{ha}^{-1}$ ) with $\mathrm{T}_{3}, \mathrm{~T}_{4}, \mathrm{~T}_{3}$ and $\mathrm{T}_{7}$ Treatment. Whereas, the lowest biological yield $\left(6.69 \mathrm{t} \mathrm{ha}^{-1}\right)$ was obtained from control condition (Table 4). Similarly, $\mathrm{T}_{5}$ showed the highest harvest index (48.84\%). On the other hand, the lowest harvest index $(30.81 \%)$ was observed from control condition which was closely followed $(44.53 \%)$ by $\mathrm{T}_{6}(50 \%$ NPKS $+5 \mathrm{t}$ vermicompost ha ${ }^{-1}$ ) treatment (Table 4 ).

\section{Conclusions}

From the above results it reveals that combined application of $70 \%$ NPKS and $2.4 \mathrm{t}$ poultry manure $\mathrm{ha}^{-1}$ produced the highest number of effective tillers, largest panicles, the maximum number to total grain per plant, highest weight of 1000 -grain as well as grain yield (7.64 tha-1) and straw yield(7.30 tha-1). Therefore, it can be recommended that $70 \%$ NPKS and 2.4 t poultry manure ha ${ }^{-1}$ combination is best for the yield of boro rice BRRI dhan 29.

\section{References}

Abedin, M. J., Rouf, M. A., Rashid, M. H. and Eaqub, M. 1999. Residual effects of TSP and Farmyard manure under renewed application of urea on the yield of crop and some chemical properties of soil. Bangladesh Journal of Agricultural Science 10(2): 100-109.

Ahmed, M. and Rahman, S. 1991. Influence of organic matter on the yield and mineral nutrition of modern rice and soil properties. Bangladesh Rice Journal 2(12): 107-112.

Apostol, E. D. F. 1989. Influence of mirasoil organic and $\mathrm{X}$-rice liquid fertilizer in combination with inorganic fertilizer on IR 66 and Bpiri 12 rice varieties. Malabon, Metro Manila, Philippines. 73.

Babu, S., Marimuthu, R., Manivanna, V, and Ramesh-Kumer, S. 2001. Effect of organic and inorganic manures on growth and yield of rice. Agriculture Science Digest. 21(4): 232-234.

BBS (Bangladesh Bureau of Statistics). 2008. Statistical Yearbook of Bangladesh. Statistics Division, Ministry of Planning, Govt. of Peoples Republic of Bangladesh. Dhaka. Bangladesh, 71p.

Bhuiyan, N. I. 1994. Crop production trends and need of sustainability in agriculture. Paper presented at the workshop. Integrated Nutrient Management for Sustainable Agriculture held at SRDI, Dhaka, Bangladesh in June 26-28. 
Chander, S. and Pandey, J. 1996. Effect of herbicide and nitrogen on yield of scented rice (Oryza sativa) under different rice cultures. Indian Journal of Agronomy, 41(2): 209-214.

FAO Rice Conference proceedings 2004, RGA 2004, USDA FAS 2004 http://www.aboutrice.com/facts/fact01.html

Fertilizer Recommendation Guide, 2005, Bangladesh Agricultural Research Council, Dhaka, Bangladesh. 60 p.

Gomez, K. H. and Gomez, A. A. (1984). Statistical Procedures for Agricultural Research. Second Edn. Wiley- Inter Science publication, JohnWiley and Sono, New York, 680 p.

Haque, M. Q., Rahman, M. H., Fokrul, I., Jan, Rijmpa,and Kadir, M. M. 2001. Integrated nutrient management in relation of soil fertility and yield sustainability under Wheat- Mung-T. aman cropping pattern. On Line Journal of Biological Science, 1(8): 731-734.

Hoque, M. A. 1999. Response of BRRI dhan 29 to sulpher, zinc and boron supplied from manure and fertilizers, M.S. Thesis, Dept. Soil Sci. (January- June, 1999, Sem.) BAU, Mymensingh.

Hossain, M. B., Islam, M. R., Rhaman, M. M. and Jahiruddin, M. 1997. Effect of integrated nutrient management on rice yield and components of BR 11 rice. Progressive Agriculture, 8(1 \&2): 83-86.

Islam, M. M. 1997. Response of BRRI dhan 30 rice to cowdung and urea- $\mathrm{N}$ in the boro season. M.S. Thesis, Dept. Soil Sci. (January-June, 1997, Sem.), BAU, Mymensingh.

Khan, M. M. R. 1998. Effect of cowdun, poultry manure and urea- $\mathrm{N}$ on the growth and yield of BRRI dhan 29. M.S. Thesis, Dept. Soil Sci. (July-December, 1998, Sem.), BAU, Mymensingh.

Meelu, O. P. and Yadvinder Singh 1991. Integrated use of fertilizers and organic manure for higher returns. Progressive Farming Punjab Agricultural University, 27: 3-4.

Miah, M. M. U. 1994. Prospects and problems of organic fanning in Bangladesh. Paper presented at the workshop on Integrated Nutrient Management for Sustainable Agriculture. Soil Resource Dev. Inst., Dhaka, June 26-28.

Nambiar, K. K. M. 1991. Long-term fertility effects on wheat productivity. In wheat for the Non-traditional Warm areas, (ed.) Saunders D.A., CIMMYT. 516-521 pp.

Rajni Rani, Srivastava, O. P. and Rani, R. 2001. Effect of integration of organics with fertilizer $\mathrm{N}$ on rice and $\mathrm{N}$ uptake. Fertilizer News, 46(9): 63-65.

Razzaque, M. M. A. 1996. Comparative study on the effect of rice straw, farmyard manure and fertilizer nitrogen on the growth and yields of BR 11 rice. M.S. Thesis, Dept. Soil Sci. (January-June, 1996, Sem.), BAU, Mymensingh.

Sharma, A. R. and Mitra, B. N. 1991. Direct and residual effect of organic materials and phosphorus fertilizers in rice (Oryza sativa) based cropping system. Indian Journal of Agronomy, 36(3): 299-303.

Singh, A. K., Nongkynrith, P. and Khan, S. K. 1999. Critical limit of zinc deficiency for predicting response of rice to zinc application on wet land rice soil of Meghalaya. Journal of Indian Society of Soil Science, 36(2): 171-172. 


